\title{
A BLESSING IN THE PHOENICIAN KARATEPE INSCRIPTION?
}

\author{
KRZYSZTOF J. BARANOWSKI \\ UNIVERSITY OF WARSAW
}

\begin{abstract}
The inscription from Karatepe (KAI 26) is a bilingual artefact in Luwian and Phoenician. Since both texts are written in a fluent and idiomatic manner, they must be interpreted independently. A comparison between them can be undertaken only after an independent reading. This way of approaching the texts calls into question the volitive interpretation of the so-called blessing in III:2-III:11 in the Phoenician version on the basis of the volitive meaning of the parallel Luwian section. Indeed, the presence of a blessing is unlikely in a royal Phoenician inscription because of its literary genre. Moreover, it is improbable that wbrk in II:2 begins a blessing since all other Phoenician inscriptions use the yiqtol ybrk to introduce one. Lines III:2-11, rather than being a request for blessing, are a description of blessing and prosperity accorded to the city by Baal and the gods.
\end{abstract}

\section{Introduction}

Since its discovery in 1946-7, the bilingual (Luwian-Phoenician) Karatepe inscription has remained the longest extant text in the Phoenician language. ${ }^{1}$ The two texts which form this bilingual artefact

* I am grateful to R. Holmstedt and A. Schade for their advice on the earlier stages of writing of this article. My particular gratitude goes to Danielle Duperreault. All responsibility for the content remains with me.

1 The text and designations of columns and exemplars those are of H. Çambel, Corpus of Hieroglyphic Luwian Inscriptions: Vol. II: Karatepe-Aslantaş: The Inscriptions: Facsimile Edition: With a Contribution by Wolgang Röllig and Tables by John David Hawkins (Untersuchungen zur indogermanischen Sprach- und Kulturwissenschaft 8.1, Berlin-New York 1999), 50-73. Alternatively one may consult H. Donner and W. Röllig, Kanaanäische und aramäische Inschriften: Band I $I^{5}$ (Wiesbaden 2002), no. 26 (hereafter $K A I$ ). Abbreviations: CIS = Corpus Inscriptionum Semiticarum ab Academia Inscriptionum et Litterarum Humaniorum conditum atque digestum, (Paris 1881-); RÉS = Répertoire d'épigraphie sémitique, publié par la Commission du Corpus Inscriptionum Semiticarum, (Paris 1900-). 
convey the same content in a form appropriate to each of the languages. Indeed, the texts in both languages follow their own syntax and style, employ idioms as well as geographical and agricultural terms specific to them, and contain expressions which betray different ways of conceptualizing the world of the divine. ${ }^{2}$ This being the state of matters, it is pointless to naïvely enquire about the original version of the inscription and it is erroneous to forcefully interpret details of one text in light of the other in order to achieve an artificial and conciliatory translation of the texts. Rather than flattening the differences, one should engage in an autonomous interpretation of each text, give priority to specific nuances, and, in this way, ground the comparative analysis on the solid base of independent understanding of the Phoenician and Luwian inscriptions. A prime example of such a way of approaching the Karatepe bilingual comes from a reconsideration of the meaning of the word wbrk (A III:2) which casts doubt upon the widely accepted volitive reading of section $\mathrm{A}$ III:2-11 in the Phoenician inscription.

\section{The Context of the Assumed Blessing Section}

In order to understand the meaning of a verb in any language, and in particular in an ancient Semitic language, it is necessary to consider individual verbs as elements in a larger verbal, and indeed narrative, constellation. This necessity comes from a simple observation that the same grammatical form may have different meanings depending on, among other things, its syntactic context, its dependence on other verbs, or the semantic input of other constituents in either the sentence itself, or in the larger narrative unit. For example, a sentenceinitial yiqtol tends to be volitive in meaning, whereas a yigtol in the medial or final position usually has an indicative meaning. Similarly, the presence of the adverbial phrase 'day and night' entails the interpretation of a yiqtol as referring to a habitual rather than

2 A detailed analysis which supports this characterization of the Karatepe bilingual is available in M.G. Amadasi Guzzo and A. Archi, 'La bilingue fenicio-ittita geroglifica di Karatepe', Vicino Oriente 3 (1980), 85-102. The same conclusions were reached by Y. Avishur who writes that the Phoenician Karatepe inscription 'reflects the grammar and syntax of the Phoenician language, its forms and style' (Phoenician Inscriptions and the Bible: Select Inscriptions and Studies in Stylistics and Literary Devices Common to the Phoenician Inscriptions and the Bible [Tel Aviv-Jaffa 2000], 172). For a more recent but shorter comparison of the Luwian and Phoenician text see R. Lebrun, 'La place du phénicien en Anatolie au premier millénaire av. J.-C.', Res Antiquae 5 (2008), 451-4. 
present-ongoing action. Therefore, the delimitation and consideration of the syntactic and discursive context of an individual verb must precede its analysis because one must be aware of the contextual factors which help to determine its meaning.

The so-called blessing section of the Karatepe inscription (III:2III:11) sits within a larger narrative framework. It is delimited, on the one hand, by the preceding account of the building of the city (II:9III:2) and, on the other hand, by the curses which follow (III:12IV:1). The curse section is well delimited by its syntactic construction in the form of a conditional clause with multiple protases and a complex apodosis and thus requires no special comments here. The relationship of the blessing section with the preceding account of building the city, however, requires some consideration. In considering it, one must keep in mind that the entire Phoenician Karatepe inscription abounds with micro-structures formed by chiasms, parallel expressions, and repetitions. These may serve as the basis for dividing the inscription into a series of smaller units. However, these sub-units should be traced within the boundaries of what appear to be greater units. This observation leads to a division of the text which differs from those proposed most recently by Younger and Schade. ${ }^{3}$ In III:2, there is no construction such as a different word order or an adverbial phrase which would signal the beginning of a major division, but the verb with the coordinating conjunction is followed by its subject, exactly as happens in II:9, II:17 and III:7. Therefore, instead of speaking about a distinct 'blessing section', one should delineate one overarching section concerning the city in lines II:9-III:11. This overarching section can be broken into four possible sub-sections: II:9-17, II:17-III:2, III:2-III:6 and III:7-11. The first two subsections can be defined as such based on the fact that the phrase $w b n$ 'nk hqrt $z$ 'and I built this city' recurs at the head of each sub-section, in II:9 and II:17. The repetition of this phrase defines them as separate sub-sections that are nonetheless to be read together. The last two sub-sections are defined on the basis of a change of the grammatical and thematic subject: in the first sub-section, III:2-6, the subject is Baal and his blessing whereas in sub-section III:7-11 the subject is the city and its prosperity.

3 K.L. Younger, Jr., 'The Phoenician Inscription of Azatiwada: An Integrated Reading', JSS 43 (1998), 13-18; A. Schade, A Syntactic and Literary Analysis of Ancient Northwest Semitic Inscriptions (Lewiston-Queenston-Lampeter 2006), $17-55$. 


\section{A BLESSING IN THE PHOENICIAN KARATEPE INSCRIPTION?}

In light of the proposed division, the Phoenician text has the structure of a double diptych. Its graphic disposition makes visible the logic of the composition. Indeed, it is immediately apparent that each subsection begins in the same manner: the verb in qatal preceded by the conjunction $w$ and followed by its subject. Needless to say, the parallel construction suggests a parallel meaning. Moreover, the verbs in each sub-section must be interpreted in a way which provides a coherent picture within a subsection itself as well as within the entire section II:9-III:11.

\begin{tabular}{|c|c|}
\hline $\begin{array}{l}\text { Sub-section A: } \\
\text { The first report on building the city }\end{array}$ & $\begin{array}{l}\text { Sub-section B: } \\
\text { The second report on building the city }\end{array}$ \\
\hline $\begin{array}{l}\text { II } 9 \text { [...] wbn 'nk hqrt z wšt } \\
\text { II } 10 \text { 'nk šm 'ztwdy k b'l wršp } \\
\text { II } 11 \text { șprm šlhn lbnt wbny 'nk b } \\
\text { II } 12 \text { 'br b'l wb'br ršp sprn } \\
\text { II } 13 \text { šb wbmn'm wbšbt n'mt wbnht } \\
\text { II } 14 \text { lb lkny mšmr l'mq 'dn wlb } \\
\text { II } 15 \text { t mpš } k \text { bymty kn l'rș 'mq' } \\
\text { II } 16 \text { dn šb' wmn'm wbl kn mtm ldnny } \\
\text { II } 17 \text { m ll bymty [...] }\end{array}$ & $\begin{array}{l}\text { II } 17 \text { [...] wbn 'nk hqrt z št } \\
\text { II } 18 \text { 'nk šm 'ztwdy yšb 'nk bn } \\
\text { II } 19 \text { b'l krntryš wylk zbḥ lkl } \\
\text { III } 1 \text { hmskt zbh ymm 'lp wb['t } \\
\text { III } 2 \text { š wb't qșr š [...] }\end{array}$ \\
\hline $\begin{array}{c}\text { Sub-section C: } \\
\text { Baal and his blessing }\end{array}$ & $\begin{array}{l}\text { Sub-section D: } \\
\text { The city and its prosperity }\end{array}$ \\
\hline $\begin{array}{l}\text { III } 2 \text { [...] wbrk b'l kr[n] } \\
\text { III } 3 \text { tryš 'yt 'ztwd bym wšlm } \\
\text { III } 4 \text { w'z'dr } l \text { kl mlk ltty b'l krntryš } \\
\text { III } 5 \text { wkl 'ln qrt l'ztwd 'rk ymm wrb } \\
\text { III } 6 \text { šnt wrš't n'mt w'z 'dr l } l \text { kl ml } \\
\text { III } 7 \mathrm{k}[. . .]\end{array}$ & 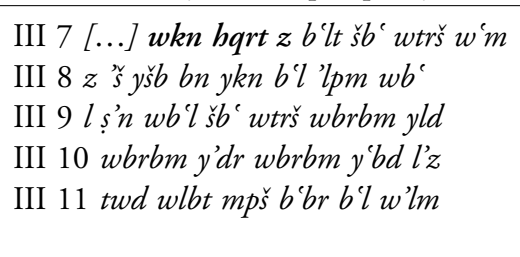 \\
\hline
\end{tabular}

Sub-section A poses no major difficulties concerning the verbs and may be translated as follows:

II 9 And I built this city, and I established

II 10 its name Azatiwadaya. For Ba'al and Resheph-

II 11 ȘPRM had commissioned me to build it. And I built it by

II 12 the grace of $\mathrm{Ba}$ al, and by the grace of Resheph-ṢPRM, with

II 13 satiation, and welfare, and with gracious living, and with peace

II 14 of mind, so that it might be a protection for the plain of Adana and for the

II 15 house of Mopsos. For in my days the land of the plain of

II 16 Adana had satiation and welfare; and the Danunians never had

II 17 night in my days. ${ }^{4}$

4 The translation is taken from Çambel, Corpus, 53. 
Problems with the interpretation of the verbs occur in the subsections of II:17-III:11. Their analysis must precede an attempt at a fresh translation.

\section{The History of Translation of II:17-III:11}

Many scholars render the problematic verbs in II:17-III:11 (wylk, $w b r k, l t t y, y k n, y l d, y^{\prime} d r$, and $\left.y^{\prime} b d\right)$ in the volitive sense:

\begin{tabular}{|c|c|}
\hline $\begin{array}{l}\text { Translations of the verbs wylk, wbrk, ltty, } \\
y k n, y l d, y^{\prime} d r \text {, and } y^{\prime} b d\end{array}$ & Source of the translation \\
\hline $\begin{array}{l}\text { 'a sacrificial order was established,' } \\
\text { 'may...bless,' 'may...give,' 'may...possess,' } \\
\text { 'may...possess,' 'may... have children,' } \\
\text { 'may...be strong,' 'may....serve;' }\end{array}$ & $\begin{array}{l}\text { F. Rosenthal, 'Canaanite and Aramaic } \\
\text { Inscriptions,' in J.B. Pritchard (ed.), } \\
\text { Ancient Near Eastern Texts Relating to the } \\
\text { Old Testament (Princeton 1969), } 654 .\end{array}$ \\
\hline $\begin{array}{l}\text { 'offri vittime,' 'benedica,' 'possa essere,' } \\
\text { 'possa essere,' 'possa essere potente,' 'sia } \\
\text { sottomesso;' }\end{array}$ & $\begin{array}{l}\text { P. Magnanini, Le iscrizioni fenicie } \\
\text { dell'Oriente: Testi, traduzioni, glossari } \\
\text { (Roma 1973), 55-6. }\end{array}$ \\
\hline $\begin{array}{l}\text { 'let...bring,' 'may...bless,' 'may...give,' } \\
\text { 'may....be,' 'may...be,' 'may...bear,' } \\
\text { '(may)...become powerful,' '(may)... } \\
\text { serve;' }\end{array}$ & $\begin{array}{l}\text { J.C.L. Gibson, Textbook of Syrian Semitic } \\
\text { Inscriptions. Vol. III: Phoenician } \\
\text { Inscriptions Including Inscriptions in the } \\
\text { Mixed Dialect of Arslan Tash (Oxford } \\
\text { 1982), 51-3. }\end{array}$ \\
\hline $\begin{array}{l}\text { 'shall...offer,' 'may...bless,' 'may...give,' } \\
\text { 'may...be,' 'may...be,' 'may...bear,' } \\
\text { 'may...become mighty,' 'may....serve;' }\end{array}$ & $\begin{array}{l}\text { K.L. Younger, Jr., 'The Azatiwada } \\
\text { Inscription,' in W.W. Hallo and } \\
\text { K.L. Younger, Jr. (eds), The Context of } \\
\text { Scripture. Vol. II: Monumental Inscriptions } \\
\text { from the Biblical World (Leiden-New } \\
\text { York-Köln, 2000), 150. }\end{array}$ \\
\hline $\begin{array}{l}\text { 'may bring,' 'may...bless,' 'because he, } \\
\text { Ba'al-KRNTRYŠ and all the gods of the } \\
\text { city give,' 'may....be owners,' 'may...bear,' } \\
\text { '(may)... become powerful,' '(may)... } \\
\text { serve;' }\end{array}$ & Çambel, Corpus, 53. \\
\hline $\begin{array}{l}\text { 'let...bring,' 'may... bless,' 'may....give,' } \\
\text { 'may...be,' 'may... possess,' 'may...have } \\
\text { children,' 'may... become powerful,' } \\
\text { 'may....serve;' }\end{array}$ & Avishur, Phoenician Inscriptions, 179. \\
\hline $\begin{array}{l}\text { 'let...be brought,' 'may...bless,' 'might } \\
\text { give,' 'may....be a mistress,' 'may...be } \\
\text { owners,' 'may...bear children,' 'may... } \\
\text { become... powerful,' 'may....serve.' }\end{array}$ & $\begin{array}{l}\text { Schade, A Syntactic and Literary Analysis, } \\
46,51 .\end{array}$ \\
\hline
\end{tabular}


The only recent translation that perceives this passage differently is that of M.S. Heiser. ${ }^{5}$ Heiser translates the phrases in question as follows: 'and they brought a sacrifice to all the molten images' (II:1920), 'now Baal-KRNTRYŠ blessed Azitawada,' (III:2-3), 'so that Baal-KRNTRYŠ and all the city gods gave to him' (III:4-5). Starting with line III:7, however, Heiser renders the verbs in the volitive sense, as do many other contemporary translators. ${ }^{6}$ According to him, this is the best translation given the flow of the material, since there is no conceptual connection between lines III:2, III:7 and the preceding account of the building of the city. Instead, Heiser maintains, the author of the inscription moves in III:7 to a new topic. ${ }^{7}$

The different possibilities of understanding of II:17-III:11 were surely perceived by the first scholars who studied the inscription. Their renderings of the passage, however, are mostly non-volitive. ${ }^{8}$ In one of the first English translations, J. Obermann proposed the following rendition:

Now I have built this citadel and I have put its name Azitawaddiya, and I have installed this god, Baal KRNTRYŠ, and he, Baal KRNTRYŠ, has blessed Azitawaddu with life, and with peace, and with mighty power over every king, in order that he, Baal KRNTRYŠ, grant to Azitawaddu long days, and many years, and pl[easant] dominion. ${ }^{9}$

In a similar vein, C.H. Gordon translates the sequence of verbs in II:17-III:11 mostly in the past tense:

And I built this city and made the name Azitawaddiyy. I dwell with Baal KRNTRYŠ and there has gone (i.e., been made) the sacrifice for the entire ritual, the Sacrifice of the Thousand Days, both in the season of plowing (=sowing) barley and in the season of harvesting the barely. And Baal KRNTRYŠ blessed Azitawadd (with) life and peace and great strength above any other king so that Baal KRNTRYS and all deities of the city might give to Azitawadd length of days and multitude of years and good authority and great strength above any other king, and this city was one of plenty (of food) and women, and this people which dwell in it constituted owners of large and small cattle and owners of

5 M.S. Heiser, 'Karatepe', in The Hebrew and Canaanite Inscriptions in English Translation (CD-ROM: Logos Research Systems, Inc. 2008).

${ }^{6}$ Karatepe A II:19-III:11 in Heiser, 'Karatepe'.

7 M.S. Heiser, e-mail message to author, November 7, 2008.

${ }^{8}$ Alt renders the blessing passage with the volitive meaning. However, even he translates the word wylk in the past tense ('brachte'). See A. Alt, 'Die phönikischen Inschriften von Karatepe', WO 1 (1949), 275.

9 J. Obermann, Discoveries at Karatepe: A Phoenician Royal Inscription from Cilicia (New Haven 1948), 39-40. 
plenty (of food) and wine, and rendering taxes and rendering adulation and rendering service to Azitawadd and to the House of Mopš by the grace of Baal and the gods. ${ }^{10}$

R. Marcus and I. J. Gelb choose a modal translation only for the verb wylk in II:19, but their translation of II:17-III:11 otherwise fluctuates between the past and present tense. In their understanding, rather than being a wish, the passage describes the past act of Baal's blessing which results in the present prosperity of the city:

And I built this town (and) I gave it the name of 'ZTWDJ (and) I settled in it Ba'al KRNTJŠ. And there shall go a sacrifice to all the molten images, a yearly sacrifice of an ox, and at the [time of pl]owing 1 sheep, and at the time of harvesting 1 sheep. And Ba al KR[N]TRJS blessed 'ZTWD with life and well-being and might strength above every king, in that he, Ba'al KRNTJŠ, and all the gods of the city gave to 'ZTWD length of days and multitude of years and good richness and mighty strength above every king. And this town was possessed of abundance and wine. And this people, which dwells in it, is possessed of cattle and is possessed of flocks and is possessed of abundance and wine. And greatly they bear (children) and greatly they honour and greatly they serve 'ZTWD and BT MPŠ because of Ba'al and the god. ${ }^{11}$

A comparison between older and more recent translations shows that scholars working in the field of Phoenician epigraphy have undergone a dramatic change of opinion: the entire section II:17-III:11 has been transformed by translations that are entirely volitive. The turning point in scholarship can likely be traced to P. Meriggi's manual of Luwian, which offers an interlinear translation of the Phoenician and Luwian versions. ${ }^{12}$ Since the Luwian verbs are volitive, scholars have started to interpret the Phoenician verbs in the same sense. Many scholars advocate that the Phoenician text be interpreted in light of the Luwian. ${ }^{13}$ However, because the Phoenician text is

10 C.H. Gordon, 'Azitawadd's Phoenician Inscription', JNES 8 (1949), 111.

11 R. Marcus and I.J. Gelb, 'The Phoenician Stele Inscription from Cilicia', JNES 8 (1949), 117-18.

12 P. Meriggi, Manuale di eteo geroglifico: Parte II: Testi - Ia Serie: I testi neo-etei più o meno completi (Rome 1967), 69-100.

13 For example, Pardee interpreted some difficulties of the Phoenician text in light of the Luwian and concluded his review of Gibson's handbook as follows: 'It must also be said that in the case of this particular inscription Gibson should have paid closer attention to the Luwian version. But so should we all have!' See D. Pardee, 'Review of Textbook of Syrian Semitic Inscriptions. Vol. 3: Phoenician Inscriptions Including Inscriptions in the Mixed Dialect of Arslan Tash by John 
written in proper, idiomatic Phoenician, one should admit the possibility of its having been independently formulated before postulating a particular meaning for a well-known Phoenician form simply due to the meaning of a corresponding Luwian word. This critique is especially true in the case of the verbs. The incongruity between the Semitic and Luwian verbal systems strongly suggests the possibility of different, contextual renderings of the verbal forms by the author of the Phoenician text. The practice of identifying as problematic the Phoenician verbs in Karatepe II: 17-III:11 is largely the product of circular reasoning: the Phoenician verbs are problematic only insofar as they fail to conform to a (by no means certain) 'primary' and parallel Luwian version. Indeed, the alleged verbal problematic is artificial: it disappears once we establish the integrity and independence of the specifically Phoenician version of the Karatepe inscription. The methodological corrective reveals the underlying grammatical coherence of the Phoenician verbal forms.

\section{4. $w y l k$ (II:19)}

In the first sub-section on the building of the city (II:9-17), the narrative advances by alternation of qatal and the uninflected narrative verb with the first person independent pronoun. In the first three phrases of the second sub-section (II:17-19), the narrative is carried out entirely with the uninflected narrative verb referring to past events. The succession of these forms firmly establishes the past temporal setting of the entire section. In line A II:19, however, the word wylk appears. ${ }^{14}$ The form by itself is morphologically ambiguous. ${ }^{15}$ Its parsing depends on the choice of the subject. The most straightforward analysis takes $z b h$ as the subject and the verb as qal yiqtol 3 masc. sing. from the root h.l.k. The second option is to take this verb as an impersonal construction with no overt subject. In this case $z b h$

C. L. Gibson', JNES 46 (1987), 137-42. This kind of reading of the Phoenician version using the Luwian text as a model is implemented in Younger, 'The Phoenician Inscription', 11-47.

${ }^{14}$ Younger argued for different word divisions and a different meaning of the word mskt. However, his proposal must be rejected as his word divisions produce an odd word order (predicate, direct object, indirect object, subject) that is otherwise not found in this inscription. In the line A III:16, which Younger points to in support of his interpretation, the subject continues from the preceding sentences and so the word order in this phrase is normal.

15 A summary of the proposals is provided in Younger, 'The Phoenician Inscription', 38-9. 
must be taken as the direct object and, considering the meaning of the verb, only Yifil semantics are suitable either in qatal (perfect) 3 masc. pl. or in yiqtol (imperfect) 3 masc. pl. ${ }^{16}$

The choice of the precise morphology of the word is of little help since both qatal and yiqtol forms can be understood as having past or future meaning. Most scholars opt for a volitive reading because they interpret the subsequent lines as a blessing. Indeed, the easiest possibility of getting a volitive meaning for the following verbal forms is by considering wylk as a jussive at the beginning of a syntactic unit that continues its volitive value. ${ }^{17}$ However, there is no element in this sentence that requires or clearly indicates the jussive or volitive value of the verb. Moreover, the verb wylk appears as part of the series of past forms. Also the following verb wbrk is qatal in form, which, in the context of narrative, usually expresses the past. Therefore, it is most probable that wylk also situates the action in the past. Since the prepositional phrases $w b^{c} t$ h $r^{\circ}$ and $w b^{t} t$ qs r suggest that the verb refers to a longer period of time and not to a single instance, wylk is preferably parsed as yiqtol past iterative, with the prefixed conjunction $w$ that has here the simple function of coordinating two clauses.

\section{5. wbrk (A III:2)}

While the term wbrk can be parsed as 3 pers. sing. qatal (perfect) with a coordinating conjunction $w$, it is frequently understood as qatal

16 An alternative interpretation of this passage, well supported by the Semitic evidence, is offered in M.G. Amadasi Guzzo, 'MSKT à Karatepe', Orientalia 69 (2000), 72-80. Note that Amadasi Guzzo understands the relevant verb wylk in the past tense ('a apporté').

17 Schade, A Syntactic and Literary Analysis, 47. One might propose yet another analysis of the word wbrk that might allow a volitive understanding of lines A III:2-11, that is, parsing this word as an imperative Piel, sing. with conjunction waw directed to Baal KRNTYŠ. Thus, the phrase could be translated: 'Now, O Baal KRNTYŠ, bless Azitawada with life and peace and mighty strength above every king!' The imperative then would mark the beginning of the volitive section. This assumption would lead one to interpret the weqatal in A III:7 as a precative qatal and the yiqtols in lines A III:8-10 as forms that continue the volitive meaning of the initial imperative of the section. Although this reading is grammatically possible, it is stylistically difficult. In the blessing formulas seen above a god is addressed in the third person and not the second person. Indeed, in Phoenician gods are never commanded with an imperative. In short, if one opts for reading lines A III:2-11 in the volitive sense, the interpretation of $w b r k$ as imperative would seem to be the best grammatical and syntactic option even though it is stylistically unfeasible. 
with conjunction $w$ playing the role of so called waw consecutive. ${ }^{18}$ Again, the most straightforward choice is to understand this verb as referring to the past and not as expressing a wish, as is the case with scholars who try to reconcile the Phoenician and Luwian versions. Moreover, two reasons make it highly improbable that wbrk expresses volitivity. The first reason is grammatical; the second is stylisticliterary.

The grammatical reason for ruling out the interpretation of wbrk as the expression of a wish is the consistent use of yiqtol, and not qatal with a waw, in similar blessing formulas in dialects of the Phoenician language. Usually the blessing contains only the verb $b r k$, in personappropriate yiqtol, at the beginning of a phrase. ${ }^{19}$ Sometimes the blessing contains a longer formulation, but the basic verbal form remains the same. ${ }^{20}$ The blessing formula can employ a verb other than brk, and be longer, but again the yiqtol form usually occurs in the sentence- or phrase-initial position. ${ }^{21}$ Exceptions to the use of yiqtol in the blessing formulas are extremely rare. ${ }^{22}$ The verb brk occurs in qatal in a letter from Saqqara but the blessing formula uses yiqtol. ${ }^{23}$ Comparison with other Northwest Semitic letters shows, however, that brktk is a part of the greeting formula in that letter, not a blessing. ${ }^{24}$ Thus, this epistolary use of brk cannot be compared to

18 Calling this form 'optative' is inappropriate. See D. Pardee, 'Review of Recherches sur les inscriptions phéniciennes de Karatepe by François Bron', JNES 42 (1983): 66. The volitive use of qatal should be compared with the Old Canaanite precative and the perfect in Classical Arabic; for these see E. Lipiński, Semitic Languages: Outline of a Comparative Grammar ${ }^{2}$, (Leuven-Paris-Sterling 2001), $\$ 54.8$, 525-6.

19 CIS I 25 a,b; I 14; I 44; I 88; I 94; I 96; KAI 32; 38; 39; 40; 41; 47; 58; 63; RÉS 1213; 1517 b; M.G. Amadasi Guzzo, Le iscrizioni fenicie e puniche delle colonie in occidente (Roma 1967), 61; Magnanini, Le iscrizioni, 41, 122, 149.

20 KAI 29: tbrky bymy; Magnanini, Le iscrizioni, 126: šrš ybrk.

${ }^{21}$ KAI 5: t'rk b'lt gbl ymt 'bb'l wšntw 'l gbl; KAI 6: t'rk b't [gbl ymt ']lb' wšntw l [gbl]; KAI 7: t'rk b't gbl ymt šptb'l wšntw 'l gbl; KAI 12: ybrk wyhww; KAI 25: ytn lh rkb'l 'rk by; KAI 29: tbrky bymy; KAI 33: tšm 'kl; KAI 43: pqt wn'm ykn ly wlzr'y wyskri mlqrt; KAI 52: hrpkrts ytn hyym l'bdy.

22 A passive participle is used once in a dedicatory inscription from Tas Silg (Malta) dating to $c$. II-I cent. BCE. This inscription also has a very unusual formulation for other details: the name of the offering person is at the beginning; the name of the divinity is at the end; the name of the offered object is lacking. The inscription reads: 'psytn brk lrbt $l$ šstrt. See Amadasi Guzzo, Le iscrizioni, 27-8.

${ }^{23}$ KAI 50: brktk lbl sppn wlkl 'l thpnhs yp lk šlm.

24 J.C.L. Gibson, Textbook of Syrian Semitic Inscriptions: Vol. II: Aramaic Inscriptions Including Inscriptions in the Dialect of Zenjirli (Oxford 1975), 125-41; J.M. Lindenberger, Ancient Aramaic and Hebrew Letters (Atlanta 2003), 8-9; 29-35. 
the Karatepe inscription. In conclusion, in light of the constant use of yiqtol in blessing formulas in Phoenician of all periods, it is highly improbable that the Phoenician writer of the inscription would employ qatal with 'waw consecutive' in the volitive meaning.

The second argument against the volitivity of wbrk comes from larger, literary-stylistic considerations. Someone well acquainted with Phoenician inscriptions might expect a blessing toward the end of the inscription, as does Gibson. ${ }^{25}$ Thus, the question of blessings in Phoenician inscriptions must be briefly investigated.

While blessing formulas are certainly quite frequent in the Phoenician corpus, they occur almost exclusively in dedicatory inscriptions. ${ }^{26}$ In many cases the blessing follows the formula kšm ${ }^{\prime} q l^{27}$ However, in many other instances, this formula is not followed by an expected blessing. ${ }^{28}$ Hence, the blessing is not an obligatory element even in dedicatory formulas. Furthermore, it should not be expected in other genres of inscription. Indeed, the royal and funerary inscriptions do not contain a blessing but rather an injunction or a curse against the person who might damage the inscription. ${ }^{29}$ The Karatepe inscription is royal or official, not dedicatory. First, it begins, like other royal inscriptions, with the personal pronoun ' $n k$ followed by the official's name and his epithets. Second, its content is typical of the royal inscriptions. Indeed, it celebrates the person of Azatiwada and his deeds. Considering its genre, one should expect not a blessing but a curse, as is the case with the Karatepe inscription (A III:18-IV:3).

The Yehawmilk inscription (KAI 10) has been compared with the Karatepe inscription in order to substantiate the claim that the latter also contains a blessing. ${ }^{30}$ This comparison is not appropriate for at least two reasons. First, the genre of the Yehawmilk inscription is mixed. Although it starts as a royal inscription and contains a curse, the blessing follows the formula wšm $q$ l wp'l ly ln'm 'she heard my

${ }^{25}$ He speaks about 'the usual concluding blessings and curses.' See Gibson Textbook, Vol. III, 43.

${ }^{26}$ CIS I 7; I 14; I 44; I 88; I 90; I 94; I 134; I 147; KAI 4-7; 12; 15; 16; 18; $25 ; 29 ; 32 ; 33 ; 38-40 ; 41 ; 43 ; 47 ; 52 ; 58 ; 61 ; 63 ; 66 ; 68 ;$ RÉS 504; 930; 1213; 1517 b; Magnanini, Iscrizioni, 12, 22, 40, 122, 126, 149; Amadasi Guzzo, Iscrizioni, $27,61,122,150$.

27 Or a similar phrase. See CIS I 88; KAI 38; 39; 41; 47; 63; RÉS 504; 1213; Magnanini, Iscrizioni, 22, 41; Amadasi Guzzo, Iscrizioni, 61.

28 CIS I 147; KAI 61 A; 68; Magnanini, Iscrizioni, 40; Amadasi Guzzo, Iscrizioni, 122, 150.

${ }^{29}$ KAI 1; 13; 14; 24.

${ }^{30}$ M.L. Barré, 'An Analysis of the Royal Blessing in the Karatepe Inscription', Maarav 3 (1982), 180-1. 
voice and did kindness to me' which is typical for dedicatory inscriptions:

I Yehaumilk king of Byblos made (them) for my lady, Mistress of Byblos, whom I called upon my lady, Mistress of Byblos, and she heard my voice and did kindness to me. May the Mistress of Byblos bless Yehaumilk king of Byblos; for he is a lawful king! (KAI 10:6-9). ${ }^{31}$

Since the Karatepe inscription is not dedicatory but royal, the discrepancy in terms of genre undermines the use of the Yehawmilk inscription as an interpretative aid for a reading of the Karatepe inscription. The second reason why the Yehawmilk inscription does not support the occurrence of the blessing in the Karatepe inscription is the grammatical form of the verb. The blessing in the Yehawmilk inscription consistently uses yiqtol (wthww, wt'rk, tbrk and ttn: 'may she give life', 'may she prolong', 'may she bless' and 'may she give'), whereas the Karatepe inscription, in the supposed blessing section, has the qatal form of brk.

In short, Phoenician formulas use yiqtol and typically occur in dedicatory inscriptions. Therefore, it is highly unlikely that $w b r k$, a qatal verb, begins a blessing section in the royal Karatepe inscription.

\section{Verbal Forms in III:7-11}

The term $w k n$ at the beginning of A III:7 should be interpreted as qatal with a coordinating conjunction $w$ in accordance with the nonvolitive interpretation of wbrk I have argued for above. Again, no element in the sentence suggests that the word $w k n$ should express a wish. The form maintains the temporal framework set by the preceding phrases and entails the interpretation of the following verbs in the past tense. The word $y s ̌ b$, in the relative clause of III:8, is not qatal; the term describes the people $\left(w^{\prime} m\right)$ of the preceding clause and is best taken as a participle. All the subsequent verbs in A III:8-11 are non-initial yiqtols. Since the volitive yiqtol occurs normally in the initial position within a sentence, the non-initial position of the yiqtols in A III:8-11 suggests their interpretation as indicative rather than volitive. They must refer to the past tense because they form a chain which begins in III:7 with $w k n$, a qatal with past reference. In

31 Gibson, Textbook, vol. III, 95. 
view of the imperfective nature of yiqtol, one should analyse the yiqtols in III:7-11 as habitual past verbs.

The interpretation of $w k n$ in III:7 as the simple past and of the subsequent yiqtols in III:7-11 as the habitual past is further substantiated by the comparison of III:2-11 with II:4-5. In fact, in lines II:4-5 the author switched from the qatal form $k n$ to the yiqtol form tk in a way similar to III:2-11. Thus, a closer look at II:4-5 allows one to understand the scribe's grammatical and literary patterns. Passage II:3-6 states: wbmqmm 's kn lpnm nšt 'm 'š yšt 'dm llkt drk wbymty 'nk 'st tk lhdy dl plkm ('and in places, which were formerly feared, in which a man was frightened to walk the road, in my days, especially mine, a woman could walk alone with spindles'). The relative clauses in II:4-5 are meant to describe and emphasize an ongoing state of fear: the verbal forms are paralleled not only by the root but also by the temporal reference. In the first relative clause we find a combination that could be considered a kind of 'periphrastic conjugation,' which consists of a finite form of the verb 'to be' followed by a predicative participle. The combination describes a habitual past state. The same habitual past meaning should be assigned to yiqtol in the second relative clause. The morphology of the word $t k$ is a source of debate, but most scholars agree that it is a yiqtol 3 fem.sing. Again, this yiqtol expresses past habitual action and opposes the former state of fear with the image of permanent, ongoing tranquility. The same past habitual reference of yiqtols occurs in III:7-11 after a similar transition from qatal to yiqtol.

\section{Overview and Translation}

The interpretation of the verbs which I proposed above allows a more coherent understanding of the structure and content of the entire inscription. Its first large section (I:1-II:9) is dedicated to the mighty deeds of Azitawada and concludes with the description of the positive changes which he himself has brought: peace and tranquillity instead of insecurity and fear. Similarly, the second large section on the citybuilding (II:9-III:11) concludes with a descriptive section that emphasizes the positive impact of Azatiwada's obedience: Baal and the gods rewarded the city with permanent prosperity. The entire inscription concludes with the curse section followed by an invocation for the eternal permanence of Azatiwada's name. The overall structure of the inscription is the last argument in favour of the following translation of II:17-III:11: 
II: 17 [...] So I built this city,

II 19 I gave it the name Azatiwadiya, I made

II: 19 Baal KRTNYŠ dwell in it. And a sacrifice was brought for all

III: 1 the molten images: the sacrifice of the days — an ox; at the time of ploughing -

III: 2 a sheep; at the time of harvesting - a sheep. And Baal KRTNYŠ blessed

III: 3 Azitawada with life, health,

III: 4 and mighty strength above every king as Baal KRTNYŠ

III: 5 and all the gods of the city gave to Azatiwada length of days and multitude

III: 6 of years, and luxurious old age, and mighty strength above every king.

III: 7 And this city was owner of abundance and new wine and those people

III: 8 who dwelled in it were owners of oxen and owners

III: 9 of flocks, and owners of abundance, and new wine. And in great numbers they bore children

III: 10 and in great numbers they became powerful and in great numbers they served

III: 11 Azatitawada and the house of MPŠ, by the grace of Baal and the gods.

\section{Concluding Remarks}

The comprehensive look at the verbal forms in the Phoenician Karatepe inscriptions shows that they are used with a degree of idiosyncrasy and mastery at the same time. The idiosyncrasy is particularly noticeable in the still not fully understood narrative forms with the first person independent pronoun. The author's mastery of the verbal system can be spotted in the use of descriptive past forms (qatal+participle, yiqtol) vs. narrative past forms. One can understand these uses only by reading the Phoenician text while paying strict attention to its peculiarities. These should not be too hastily compared with the Luwian version. The same caution is recommended to grammarians in using quotations from the Karatepe inscription to interpret the verbal system of the Phoenician language in general.

Address for correspondence: k.baranowski@alumni.utoronto.ca 